OOPEN ACCESS

International Journal of Management \& Entrepreneurship Research

P-ISSN: 2664-3588, E-ISSN: 2664-3596

Volume 4, Issue 1, P.No. 13-25, January 2022

DOI: 10.51594/ijmer.v4i1.280

Fair East Publishers

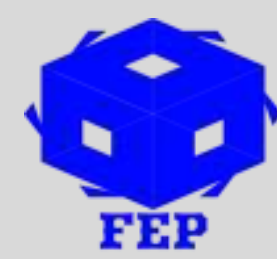

Journal Homepage: www.fepbl.com/index.php/ijmer

\title{
THE EFFECT OF HUMAN RESOURCE PLANNING ON ORGANIZATIONAL PERFORMANCE: A STUDY OF SELECTED BREWERIES IN THE SOUTH-EAST, NIGERIA
}

\author{
Okafor, Joy Ndidiamaka ${ }^{1}$, Okonkwo, Rebecca Eberechukwu ${ }^{2}, \&$ \\ Blessing Obiageli Essell ${ }^{3}$ \\ $1,2,3$ Department of Business Administration, \\ Nnamdi Azikiwe University, Awka, Nigeria
}

Corresponding Author: Okafor, Joy Ndidiamaka

Corresponding Author Email: ae.arachie@unizik.edu.ng

Article Received: $10-12-21$

Accepted: $30-12-21$

Published:03-01-22

Licensing Details: Author retains the right of this article. The article is distributed under the terms of the Creative Commons Attribution-Non Commercial 4.0 License (http://www.creativecommons.org/licences/by-nc/4.0/), which permits non-commercial use, reproduction and distribution of the work without further permission provided the original work is attributed as specified on the Journal open access page.

\begin{abstract}
This study examined the effect of manpower planning on organizational performance in the Brewery industry in South-East, Nigeria. The literature review section touched on all the fourmain sections of the review which include conceptual review, theoretical framework, theoretical exposition and empirical review. The study adopted descriptive survey design and used summary and descriptive statistics as well as regression analysis as the main tools of analysis. All tests were conducted at 0.05 level of significance. Preliminary results indicated that FStatistic of 18.029 is statistical significant and as such, the model was considered valid for predictions. The regression coefficient showed that 61.7 percent relationship exists between the dependent and independent variables. The coefficient of determination also showed that 52.9 percent variation in the dependent variable can be explained by the regressors. Major findings are that manpower planning in the area of forecasting to anticipate employees number and skills/expertise level have significant positive effect on organizational performance. It was concluded that human resource planning is very essential for optimal performance in the
\end{abstract}


brewery industry. The study recommended among others that the issue of human resource planning should be treated in the organization with the seriousness that it deserves.

Keywords: Human Resource Planning, Manpower Forecasting, Manpower Planning, Organizational Performance, Brewery Industry and Southeast Nigeria.

\section{INTRODUCTION}

Manpower planning is one of the functions of management and it is highly indispensable in the achievement of organizational goals. There is need to plan for the various resources that organization use, especially the human resource which happens to be the most crucial of all the resources in the organization (Anya, Umoh and Worlu, 2017). This is because, it is the personnel that coordinate and utilize other resources toward the attainment of organizational goals. Besides, in this era of global competition and struggle for market share in the business space, it is only the organizations with the right caliber of personnel that can survive the intense competition in the business environment. In other words, the route to competitive advantage is the acquisition and proper utilization of the manpower in the organization (Lunenburg, 2012).

When organizations are provided with everything they need to succeed excluding the personnel, the composition of the workforce will be the determining factor in the achievement of competitive advantage (Noe, 2012). Therefore, manpower or human resource planning is at the heart of personnel management. This underscores the need to plan, recruit, train and place employees whether new or old in order to ensure effective and efficient functioning of the organization (Ezeani, 2006). In the opinion of Amin and Islam (2013), the main aim of manpower planning is to maintain the most appropriate staffing of all calibre of personnel across the organization departments and section. It is not just the number, but it includes the mix of different skills requirement in the organization. This is because, the essence of planning in this regard is to have the right people, in the right number, with the right knowledge in the right jobs, in the right places, at the right time and at appropriate cost to the organization. As could be seen, the process demands that the planner or planners should have good knowledge of the entire units of the organization being served.

The word "planning" is very central in management functions because it provides the framework for the implementation of other crucial managerial functions such as organizing, directing, coordinating, controlling, budgeting and staffing. It is by its nature purposeful and futurist because it involves the determination of specific objectives as well as course of actions, strategies, policies, programmes and procedures for achieving them (Okeke and Egboh, 2009). It is a process that allows for rapid skills update for the necessary innovation and creativity that the organization requires (Du Plessis, Nel, Winter and Ngalo, 2011). Helavalade and Julius (2017) posit that human resource planning is the bedrock of very successful organization and organizational performance is an indicator of the prosperity and sustainability of the business as well as the owners (Robbins, Judge and Sanghi, 2009). In the light of the above, this study examines the effect of manpower planning on organizational performance by evaluating the effect of manpower forecasting to ascertain optimal level of staffing in terms of number and skills diversity. 


\section{Statement of the Problem}

One of the problems confronting management in any organization is how to match people with jobs. But experts in the field have continued to ask questions on whether it is most appropriate to design jobs to suit the employee or get the employee fit into a job position. Whichever is optimal, it is to be noted that one of the functions of the management in any organization, and a very crucial one at that, is the determination of the organization's manpower need. It has been widely acknowledged that human resource is the most critical of all the resources that an organization needs to function effectively. Unfortunately however, many organizations have treated this all important management function with less importance, especially in the private sector organizations because in the public sector organizations, there are usually established vacant posts which the appropriate department often takes care of.

Many organizations in the private sector, even the so called large organizations do not have well-articulated succession plan and this has serious cost implications to the organizations in the areas of excessive recruitments, training and transfers. The realities of the time both in the internal and external business environments, has made organization's human resource planning to determine the number required as well as the skills diversity, more imperative now than ever. Furthermore, the unpredictable nature of human asset, which changes like weather has made continuous planning and review to determine optimality in demand and supply very mandatory. The study, on this note, therefore evaluates the effect of manpower forecasting to determine appropriate number of employees and their skills/expertise diversity on organizational performance.

\section{Objectives of the Study}

The broad objective of the study is to examine the effect of manpower planning on organizational performance, using selected firms in the brewery industry located in the South East of Nigeria as the study area. However, the specific objectives are to:

(i) Ascertain the effect of manpower forecasting with a view to determining the optimal number of employees on organizational performance.

(ii) Evaluate the effect of manpower forecasting with a view to determining the optimal skills level on organizational performance.

\section{REVIEW OF THE RELATED LITERATURE}

\section{Conceptual Review}

\section{Manpower Planning}

Dialoke and Duru (2017) conceive of human resource planning as a process of aligning an organization's human capital to its business plan to achieve its mission.In other words, it means ensuring that an organization currently has and will continue to have the right people with the right skills in the right jobs, at the right time. The people must be at their assignments, performing efficiently and effectively. In a related definition, Ede and Dialoke (2020) see human resource planning as a means by which manpower need of an organization is anticipated and at the same time prepare for retirement of workers with the intention of replacing the exiting with the new ones to avoid incurring personnel gap in the organization. Management Study Guide (2017) defines manpower planning as a process of gathering and using relevant information to support decisions on human resource management on how to invest resources in manpower activities of the organization. Finally, manpower planning can be defined as a 
strategy for the procurement, development, allocation and utilization of an organization human resource for achievement of organizational goals (Maina and Kwasira, 2015).

\section{Manpower Forecasting}

Armstrong (2012) defines forecasting of manpower demand in an organization as the process of estimating the present and future number of people an organization would need as well as the skills and competencies they should equally possess. The traditional approach of calculating the demand is characterized by making use of ratios to devise strategy in order to confront opportunities and threats from within and external environments (Pradeesh, 2011). Therefore the process of finding out the likely personnel needs of an organization known as manpower forecasting is adopted in an organization to avoid unnecessary idle hands or shortages which may arise as a result of unscientific guess work for organizational human resource needs.

\section{Organizational Performance}

Kaplan and Norton (1992) cited in Anya, Umoh and Worlu (2017) define organizational performance as a set of financial and non-financial indicators capable of assessing the degree to which organizational goals and objectives have been accomplished. George (2017) defines organizational performance as a process of ensuring that firms' resources are properly used in pursuit of their goals. Similarly, Abdel-Maksoud, Asada and Nakagwa (2008) define organizational performance as one of the most imperative measures in evaluating organizations' activities and their environment. To Bibheti (2008) cited in Salou, Adeniji and Oyewunmi (2014), organizational performance is the strength and ability of a firm to achieve its goals through employees' retention, wide-range management style, internal work motivation, greater commitment, job satisfaction and career opportunities which have significant and important effects on organizational success.

\section{Extant Literature}

\section{Practice of Human Resource Planning and Organizational Performance}

Manpower planning is anchored on identifying in the number of employees and their skills level that an organization would needs to operate with towards the achievement of its set objectives and goals. It is an ongoing process of regular/continued structured planning. The process confirms that employees are in the right number and that they are with the necessary skills as required in the organization for effective and efficient performance. That is, the planning ensures there are neither surplus nor shortage of employees. According to Parker and Caine (2016), such articulations are quite necessary to save the organization from unwanted situations of either shortage of needed personnels or excess of it which leads to presence of idle hands with its negative consequences. Hassan (2013) stresses the point further by stating that failure to properly articulate and implement the three fundamental functions of human resource planning which includes labour, labour forecast, managing demands for employees and available supply in the market and keeping a balance between labour supply and demand predictions will pose great problems to the organization in terms of cost and expertise (skilled personnel) which actually lowers the level of competitiveness that the organization would have.

\section{Forecasting Human Resource Needs and Organizational Performance}

When forecasting is carried out in any event, the outcome may not be hundred percent correct however, it is sufficient that it provides a good guide to the purpose so that level of derailment can be within the range of tolerable limit. Forecasting manpower needs for an organization involves a practical level determination of employee size and type that an organization would 
need to perform effectively (Mkandatsama and Nyanhete, 2017). Pradeesh (2011) observes that it is about the present and future manpower needs of the company. He states further that the demand for the organization's product or service is an integral part of the optimization. Hence it is imperative to project ahead of time, the market as well as the sales figure so that the personnel needed to serve the projected output can be met with very minimal waste if at all.

Similarly, Noe (2012) posits that forecasting of manpower needs of an organization, which in itself is a process of estimating both the present and future number of personnel and their capabilities or likely skills and competencies they ought to have, is affected by certain factors such as organizational budget constraints, turnover due to resignations, terminations, transfers/relocations, retirements and new technology in place. Other factors are decision to upgrade the quality of services provided and minority hiring goals. He observes that failure to estimate the future manpower needs of the company often leads to last minute decision-making which is not always proper for managers in the organization. According to Shikha and Karishma (2012), forecasting of organization's manpower need has become a means of facilitating desired performance in the organization because of the indispensable role employees play in organization's day-to-day operations. Such exercises, in their opinion, help organizations to determine ahead of time not only the number of employees needed but also the needed skills or expertise that can enable the organization to perform effectively and achieve the desired competitive advantage for sustainability in the company.

\section{Theoretical Framework}

The theory upon which the study is anchored is the Decision Making Theory propounded by Herbert Simon in (1957). The theory is contained in his book 'Administrative Behaviour.' In the book, he opined that the most critical factor in achievement or organizational objective was correct or intelligent decision making. By this, he meant the optimum rational choice between alternative courses of action. According to him, decision making is the heart of Administration and it follows that understanding of organizational activities revolves on the decision making process. He remarks that it is the pumping center which galvanizes other units of the organization into action.

Specifically, manpower planning revolves in decision making. In other words, it is primarily based on making decision on manpower in an organization. It can actually be called manpower decision-making. The implication is that manpower planning and staff development utilizes decision making process toward the realization of organizational goals. Therefore, organizational goal is a dependent variable that interacts with other variables to give organizations their peculiar and dynamic characteristics.

\section{Relevance of the Theory to the Study}

Relating this theory to manpower planning and organizational performance, organization at the initial stage of establishment will use rational decision theory because the situation calls for that. Then, the organization will analyze all reliable information relating to manpower and organizational objective before any action plan relating to recruitment, promotion, displacement, training and development can be drawn. Note that decision usually take place in manpower planning in order to have improvement on already existing manpower which results to manpower development. Thus the issue under investigation in this study has been effectively analyzed under the framework of decision making theory as propound by Herbert Simon in 1957. 


\section{Empirical Review}

Igbokwe, Osakede and Anazodo (2017) did a study on the effect of manpower planning and development in Lagos State, Nigeria, using the civil service performance as the dependent variable. The study design was descriptive survey. The results of the analysis showed that nature of manpower planning and development curriculum has positive effect on Lagos State Civil Service performance. It showed also that manpower planning and development have positive effect on the attainment of Lagos State objective. It was concluded that the service should among otherscontinue to improve on the current manpower planning strategy and continue to update its manpower development curriculum. In another study, Edeh and Dialoke (2020) conducted an investigation on the effect of human resource planning on organizational performance in the hospitality industry in Nigeria. The study used survey method and the result of the analysis showed that human resource planning dimensions namely; adequate funding, competence, age, and cultural background have significant positive effect on organizational performance. It was concluded that human resource management should focus on financial capability of the firms as well as age, competence and cultural orientation of the prospective employees while making human resource planning.

In a related study, Dialoke and Dura (2017) examined the effect of workforce planning on organizational performance in a selected media houses in Imo State, Nigeria. The study adopted descriptive survey design. The result of the analysis indicate that workforce planning is significantly associated with organizational performance. The study concludes that effective workforce planning will enhance organizational performance. In the same vein, Afzal, Mahmood, Sherazi, Sajid and Hassan (2013) investigated the effect of human resource planning on organizational performance in Telecom sector of Pakistan. The study made use of descriptive survey design. Findings from the study showed that significant positive relationship exists between human resource planning and organizational performance in the Telecom sector of Pakistan. The study concludes that adoption of modern human resource planning practices will lead to enhanced performance in the organization.

Anya, Umoh and Worlu (2017) evaluated the effect of human resource planning on organizational performance in the oil and gas industries located in Port Harcourt, Rivers State, Nigeria. Design of the study was descriptive survey and findings suggest that significant positive relationship exists between human resource planning and organizational performance in the sector. The study concludes that manpower audit is very essential in all oranizations to determine in advance the demand and supply situation in the organization and labour market prior to the recruitment of employees. In another study, Olusanya, Awotungase and Ohadebere (2012) examined the impact of effective human resource planning on firm's productivity by using Sterling Bank, Nigeria, PLC as the study area. The study which used descriptive survey design as its method, found from the analysis of data that effective human resources planning has positive and strong correlation with organizational productivity. It was concluded that human resource planning is a necessary and sufficient condition for improving and sustainingproductivity in the service industry such as banking. In a related study, Nwichi and Chukwuka (2017) examined manpower planning as a veritable tool for enhancing performance in the public sector organizations. The study adopted context analysis and found that effective regulatory capability on the part of government for necessary enforcement of manpower policies, will improve performance in the sector. 
Bello, Kashaam, Ologbenla and Patrick (2017) did a study to determine the effectiveness of human resource planning on employees' performance in the oil and gas industry in Nigeria. The study design was survey method. Result showed significant effect of human resource planning on employee performance. Omoankhanlan (2013) examined effect of human resource planning practices on firms performance. The study adopted descriptive survey design. The result showed that positive and significant relationship exists between human resource planning and organizational efficiency. Al-Riyami and Banu (2019) did a study on the influence of human resource planning on organizational performance in Sultanate of Oman. The study made use of descriptive survey design and the result of its correlational analysis showed that human resource planning is closely linked to organizational performance in the Omani Ministries.

Effect of forecasting manpower demand on organizational effectiveness and efficiency was investigated by Mutua (2019) through the use of descriptive survey design. The result showed that manpower forecasting can be a strong means of achieving organizational effectiveness and efficiency but many ministries in Nairobi, Kenya were not making use of it. The study concludes that ministries in Nairobi, Kenya should endeavour to make use of forecasting as the instrument of achieving optimal staff level for the ministries. In a related development, Samwel (2018) examined human resource planning as an important practice of anticipating future human resource requirement (number and skills level) of the organization. Through content analysis approach, the study established that there is a significant relationship between human resource planning (anticipating of skills or expertise level of the employees) and organizational manpower requirement and consequently organizational performance. The study concludes that continuous practice of manpower forecast will always give the organization a competitive edge in the industry.

\section{METHODOLOGY}

The design used for the study is descriptive survey design. The choice of the design was informed by the fact that the data is primary in nature and the results from the analysis would be generalized for the entire population of interest. The study is being conducted in the SouthEast of Nigeria, covering some breweries located in the states within the zone. Senior and operational staff of Sabmiller Brewery PLC Onitsha, Anambra State and those of Nigeria Breweries PLC, Ama in Enugu State are the target population. From a pilot study commissioned by the researcher, 973 and 1005 of the mentioned categories of workers were identified from the companies respectively thus making the total population of the study be 1,978 . The sample size (333) for the study was determined through the application of Taro Yamani's Statistical formula. In order to determine the sample to be allocated to each firm, we made use of proportionate sampling technique. An item structured instrument designed in a Likert scale format was used to collect the relevant data from the respondents on all issues relating to human resources planning and its effect on organizational performance. The instrument was validated in both face and content by the experts in the field. It was also tested for reliability through the method of test re-test. By applying Spearman rank order correlation on the two sets of data generated at two intervals, the coefficients for the two research questions were 0.83 and 0.80 with average coefficient of 0.82 thus showing that the instrument is 82 percent reliable. Direct questionnaire distribution approach was deployed in this study as it helped to assess whether the respondents actually understood the questionnaire items. The method also reduced the volume of non-response which usually occur in surveys of this nature. Out of the 333 copies of 
the instrument distributed, 301 were completed and returned. Thus, showing a response rate of 90.4 percent. With regard to the method of analysis, the generated data were analyzed through summary and descriptive statistics as well as Pearson correlation and multiple regression. All tests were done at 0.05 level of significance.

\section{DATA PRESENTATION AND ANALYSIS}

\section{Presentation of Data}

Table 1

\section{Correlation Matrix}

\begin{tabular}{|c|c|c|c|c|}
\hline Variables & & $\begin{array}{l}\text { Organizational } \\
\text { Performance }\end{array}$ & $\begin{array}{c}\text { Forecasting for } \\
\text { number of } \\
\text { employees } \\
\text { required } \\
\end{array}$ & $\begin{array}{c}\text { Forecasting for } \\
\text { skills requirement }\end{array}$ \\
\hline \multirow{4}{*}{$\begin{array}{l}\text { Organizational } \\
\text { Performance }\end{array}$} & Pearson & 1 & $.501 * *$ & $.625^{* *}$ \\
\hline & Correlation & & & \\
\hline & Sig.(2-tailed) & & .000 & .000 \\
\hline & $\mathrm{N}$ & 301 & 301 & 301 \\
\hline \multirow{3}{*}{$\begin{array}{l}\text { Forecasting for } \\
\text { number of employees } \\
\text { required }\end{array}$} & Pearson & $.501 * *$ & 1 & $.522 * *$ \\
\hline & $\begin{array}{l}\text { Correlation } \\
\text { Sig.(2-tailed) }\end{array}$ & & & .000 \\
\hline & $\mathrm{N}$ & 301 & 301 & 301 \\
\hline \multirow{3}{*}{$\begin{array}{l}\text { Forecasting for skills } \\
\text { requirement }\end{array}$} & Pearson & $.625 * *$ & $.522 * *$ & 1 \\
\hline & $\begin{array}{l}\text { Correlation } \\
\text { Sig.(2-tailed) }\end{array}$ & .000 & .000 & \\
\hline & $\mathrm{N}$ & 301 & 301 & 301 \\
\hline
\end{tabular}

Correlation analysis presented in Table 1 shows that strong and positive relationships exist between the dependent and independent variables as well as among independent variables. It shows also that there is no presence of multicollinearity or orthogonal relationships in the model. The implication is that regression analysis can be performed on the data without having a spurious result.

Table 2

Results of Analysis of Variance (ANOVA) for the Model

\begin{tabular}{lccccc}
\hline $\begin{array}{l}\text { Source of } \\
\text { Variation }\end{array}$ & $\mathrm{df}$ & Sum of Squares & Mean Squares & F-ratio & Sig. \\
\hline Regression & 4 & 509.275 & 127.319 & 18.029 & $.000^{\mathrm{a}}$ \\
Residual & 45 & 317.806 & 7.062 & - & \\
\hline Total & 49 & 827.081 & - & & \\
\hline
\end{tabular}

a. Predictor: (constant), Forecasting to anticipate number of employees required and forecasting to anticipate the b. Dependent variable: Organizational Performance Source: Field Survey, 2021

Table 2 is the presentation of the result of ANOVA for the model and it shows that F-value of 18.029 is statistically significant and, therefore, the model is fit and valid for any predictions because 0.000 is less than 0.05 significance level. 
Table 3

Regression Results for the Model

\begin{tabular}{cccccc}
\hline Model & $\mathrm{R}$ & $\mathrm{R}^{2}$ & $\begin{array}{c}\text { Adjusted } \\
\text { R Square }\end{array}$ & $\begin{array}{c}\text { Standard Error of the } \\
\text { Estimate }\end{array}$ & $\begin{array}{c}\text { Durbin Watson } \\
\text { Stat. }\end{array}$ \\
\hline $\mathrm{I}$ & $0.617^{\mathrm{a}}$ & 0.529 & 0.401 & 0.42537 & 1.853 \\
\hline
\end{tabular}

a. Predictor: (constant), Forecasting to anticipate number of employees required and forecasting to anticipate the skill level or expertise required

Source: Field Survey, 2021

Regression results presented in Table 3 shows that regression coefficient ' $R$ ' has a value of 0.617 and it implies that 61.7 percent relationship exists between dependent and independent variables in the model. Also, the coefficient of determination represented by ' $\mathrm{R}$ ', with a value of 0.529 means that 52.9 percent variation in the dependent variable can be explained by the independent variables. The Durbin Watson statistics of 1.853 shows that the model does not contain any serial autocorrelation.

Table 4

Unstandardized and Standardized Coefficients, $t$-value and Significance Level

\begin{tabular}{|c|c|c|c|c|c|}
\hline \multirow[t]{2}{*}{ Model } & \multicolumn{2}{|c|}{$\begin{array}{l}\text { Unstandardized } \\
\text { Coefficients }\end{array}$} & \multirow{2}{*}{$\begin{array}{c}\begin{array}{c}\text { Standardized } \\
\text { Coefficients }\end{array} \\
\text { Beta } \\
\end{array}$} & \multirow[t]{2}{*}{$\mathrm{t}$} & \multirow[t]{2}{*}{ Sig. } \\
\hline & $\beta$ & Std. Error & & & \\
\hline 1 (Constant) & .185 & .307 & - & -608 & .435 \\
\hline $\begin{array}{l}\text { Forecasting to anticipate required number } \\
\text { of employees }\end{array}$ & .361 & .075 & .511 & 10.205 & .000 \\
\hline $\begin{array}{l}\text { Forecasting to determine required skills } \\
\text { level of the employees }\end{array}$ & .498 & .059 & .473 & 3.209 & .001 \\
\hline
\end{tabular}

a. Dependent Variable: Organizational Performance

Source: Field Survey, 2021

Table 5

Post Estimation (Multicollinearity) Test Results

\begin{tabular}{llllll}
\hline \multirow{2}{*}{ Model } & \multirow{2}{*}{ Eigen Value } & \multicolumn{2}{c}{ Condition Index } & \multicolumn{2}{c}{ Variance Proportion } \\
\cline { 3 - 5 } & & & Constant & FNE & FSR \\
\hline 1. & 3.521 & 1.005 & .00 & .00 & .00 \\
2. & .064 & 6.247 & .07 & .04 & .22 \\
3. & .082 & 7.501 & .08 & .21 & .32 \\
\hline
\end{tabular}

a. Dependent Variable: Organizational Performance

Source: Field Survey, 2021

Table 5 shows there is no presence of multicollinearity relationship in the model both eigen values and condition index levels based on the specifications.

\section{Statement and Verification of Hypotheses}

The hypotheses that were formulated to guide the objective of the study as well as strengthen the analysis were re-stated and tested in this section of the analysis:

1. Ho: Forecasting to determine the required number of employees the organization would need does not have significant positive effect on organizational performance.

.2. $\mathrm{H}_{\mathrm{O}}$ : Forecasting to anticipate the skills/expertise level the organization would need does not have significant positive effect on organizational performance. 


\section{Interpretation of Regression Results}

We selected and interpret the results as presented in Table 4. Accordingly, the coefficient of forecasting to estimate the number of employees an organization would need to be optimal in performance, represented by $\alpha_{1}$ in the model has a value of 0.511 and it means that when it is increased by one unit, organizational performance will increase by 51.1 percent if other factors in the model are held constant. There is equally and evidence that the coefficient is significant given the t-value of 10.205 and its corresponding probability level of 0.000 which is less than 0.05 significance level. Consequently, the null hypothesis was rejected while the alternative which suggests that forecasting to determine the number of employees an organization would need to be optimal have significant positive effect on organizational performance was accepted. In the same vein, coefficient of forecasting to anticipate the require skills/expertise level of the employees for an organization to be optimal represented by $\alpha_{2}$ has the value of 0.473 . It means that when it is increased by one unit, organizational performance will increase by 47.3 percent if other variables in the model are held constant. Similarly, the t-value of 3.209 and its probability level is an indication that the coefficient is significant because 0.001 is less than 0.05 significance level. Therefore, we conclude that forecasting to estimate employees' skills/expertise level for optimal performance have significant positive effect on organizational performance.

\section{Discussion of Research Results}

The result of the first test of hypothesis showed that manpower planning (forecasting to determine the number of employees that would be optimal for the organization) have significant positive effect on organizational performance. The result is consistent with that of Mutua (2019) when he found from his study that manpower forecasting to determine the future number of employees an organization would need can be a strong means of achieving organizational effectiveness and efficiency. Human resource planning entails many activities within human resource management in an organization and forecasting to anticipate the personnel need of the organization is one of the most crucial activities in the domain. Even though, forecasting may not provide the exact number, it will certainly help in preventing the acquisition of unnecessary excessive number during recruitment exercise. Forecasting also provides the necessary guide against shortages arising from turnover, retirement, termination, etc. Essentially, it facilitates replenishment in terms of sudden drop in the number of personnel for any reason. The fact that many organizations, even the so called large ones, do not take the issue of manpower planning very serious, it does not diminish its importance in effective and efficient human resource management towards the realization of organizational goals.

Similarly, the result of the second test of hypothesis suggests that manpower planning in the area of forecasting to anticipate future employee skills/expertise level for optimality in the organization, have significant positive effect on organizational performance. The result like in the first test supports the work of Samuel (2018) when he found that significant strong and positive relationship exists between human resource planning (forecasting to determine optimal level of employees' skills/expertise for the organization) and organizational performance. Forecasting to determine employees' skills/expertise level required makes it easy for the organization to always overcome performance gap among the employees. The idea is that when employees' skills level are determined well ahead of time, proper placement and job/task assignment becomes very easy with the accompanying job satisfaction that such exercises 
attract. Therefore, effect of planning of organizations' manpower need is one sure way of achieving great accomplishment in the organization.

\section{CONCLUSION}

The study examined the effect of manpower planning on organizational performance in the brewery industry. Human resource planning is very essential for effective performance of the organization. As the results of the analysis have indicated, forecasting manpower needs of the organization both in terms of number and skills/expertise level, have significant positive effect on organizational performance, including financial performance. The results underscore the need for the practice by both small and large organizations. Determination of future manpower need of an organization well ahead of time both in terms of number and the skills level helps the organization to avoid the acquisition of idle hands and performance gap in the the short and long-runs. It encourages optimality and the achievement of competitive advantage in the organization.

\section{Recommendations}

1. Human resource managers or any other persons that is responsible for manpower planning in the organization should take the issue of manpower planning in the area of forecasting to anticipate optimal employee number very serious. This is because it has been found to contribute substantially to the realization of organizational goals.

2. Manpower planning encompasses many activities including forecasting to anticipate employee skills/expertise levels. Human resource/personal managers should see it as a point of duty to continually carry out the forecasting exercise because of its efficacy in effective and efficient management of the organization.

\section{References}

Abdel-Maksoud, A., Asada, T., \& Nakagawa, M. (2008). Performance measures, managerial practices and manufacturing technologies in Japanese manufacturing firms: state of the art. International Journal of Business Performance Management, 10(1), 1-16.

Afzal, F., Mahmood, K., Sherazi, S.M.R., Sajid, M., \& Hassan, M. (2013). Effect of human resource planning on organizational performance. Information and Knowledge Management, 3(2), 173-182.

Al-Riyami, F.A., \& Banu, R. (2019). The influence of human resource planning on organizational performance in Sultanate of Oman. Emerging Global Business Paradigms and Contemporary Management Issues (EGBPC) April 2019.

Amin, M.R., \& Islam, M.J. (2013). Organizational effectiveness and efficiency through manpower planning and development: a study of selected service and manufacturing organizations of Bangladesh. World Journal of Social Sciences, 3(5), 49-66.

Anya, C.J.P., Umoh, G.I., \& Worlu, G. (2017). Human resource planning and organizational performance in oil and gas firms in Port Harcourt. International Journal of Advanced Academic Research in Social and Management Sciences, 3(9), 110-129.

Anya, E.J.P., Umoh, G.I., \& Worlu, G. (2017). Human resource planning and organizational performance in oil and gas firms in Port-Harcourt. International Journal of Advanced AcademicResearch/Social Sciences and Management Sciences, 3(9), 110-129.

Armstrong, M. (2012). A handbook of personnel management practice. (13th Ed.). London: Kogan Page Limited. 
Bello, B.A., Kashaam, H.D., \& Ologbenla, P. (2017). Effective human resource planning and employee's performance in the oil and gas industry in Nigeria. JORIND, 15(2), 151-157.

Dialoke, I., \& Duru, M.I. (2017). Effects of workforce planning on organizational performance: a study of selected media houses in Imo State, Nigeria. International Journal of Social Sciences and Management Research, 3(2), 1-7.

Du Plessis, A., Nel, P., Winter, A., \& Ngalo, O. (2011). Human resource management. Eight edition. Oxford University Press, Southern Africa.

Edeh, F.O., \& Dialoke, I. (2020). Effects of human resource planning on organizational performance in the hospitality sector of the Nigerian economy. Business Perspective Review, 2(1), 1-12.

Ezeani, E.O. (2006). Fundamentals of public administration. Enugu: Snaap Press Ltd.

George, N.R. (2017). Examples of organizational performance management. Retrieved from http://smallbusiness.chron.comexamples-organizationalperformance-management11508.html.

Hassan, O. (2013). SCM and Organizational performance: strategy and innovation aspect. (Ph.D), University of Engineering and Technology, Lahore.

Helavalada, W., \& Julius, T.N. (2017). Significance of manpower planning for effective utilization of human resource in an organization: a conceptual approach. International Journal of Business and Management Invention, 6(8), 16-29.

Igbokwe, I., Osakende, I.C.O., \& Anazodo, R.O. (2017). The effect of manpower planning and development in Lagos State (Nigeria) Civil Service performance. International Journal of Human Resource Management, 11, 201-243.

Igbokwe, I.C.J., Osakede, K.O., \& Anazodo, R.O. (2017). The effect of manpower planning and development in Lagos State civil service, Nigeria on employees performance. Africa's Public Service Delivery and Performance Review, 2(4), 76-116.

Ikeagwu, K.I. (1997). Groundwork of research method and procedure. In Ejike D.C. (ed.). Effect of Employees reward management on organizational performance: a study of selected banks in Awka, Anambra State. Journal of Business and Management Studies, 2(3), 109-121.

Lunenburg, F.C. (2012). Human resource planning: forecasting demand and supply. International Journal of Management, Business and Administration, 15(1), 89-98.

Maina, D.K., \& Kwasira, J. (2015). Role of human resource planning practices on employees' performance in county governments in Kenya: a study of Nakuru county. International Journal of Economics, Commerce and Management, 3(5), 1569-1580.

Management Study Guide (2017). Human resource planning. Retrieved from http://www.managementstudyguide.com/humanresourceplanning.htm

Mkandatsama, P., \& Nyanhete, T. (2017). Human resource planning in an unstable economy: challenges faced. A case of state universities in Zimbabwe. International Journal of Asian Social Sciences, 7(3), 206-217.

Mutua, A.M. (2019). The impact of human resource planning (manpower forecasting) on organizational performance in the Ministry of Health headquarters (Masters Thesis in Public Administration), University of Nairobi, Nairobi, Kenya.

Noe, R.A. (2012). Human resource management: gaining a competitive advantage. New York: McGraw-Hill. 
Nwichi, C.K., \& Chukwuka, E.U. (2017). Manpower planning as a tool for enhancing the performance of public sector organizations in Nigeria. Arabia Journal of Business and Management Review (Nigerian Chapter), 4(3), 11-18.

Okeke, M.I., \& Egboh, E.A. (2009). Fundamentals of personnel management in Nigeria. Enugu: Bismark Publications.

Olusanya, S.O., Awotungase, S.A., \& Ohadebere, E.C. (2012). Effective planning and organizational productivity: a study of Sterling Bank of Nigeria PLC. IOSR Journal of Humanities and Social Sciences (JHSS), 5(5), 31-39.

Omoankhanlen, J.A. (2013). Human resource planning: a key factor in ensuring the effectiveness and efficiency of organization. Journal of Emerging Trends in Economics and Management Sciences (JETEMS), 4(4), 388-396.

Parker, B.J., \& Caine, D. (2016). Holonic modelling: human resource planning and the two faces of Janus. International Journal of Manpower, 17(8), 30-45.

Pradeesh, N.M. (2011). Human resource planning and development. Calicut University, P.O,. Malappuram, Kerala, India - 673-635.

Robbins, S.P., Judge, T.A., \& Sanghi, S. (2009). Organizational behaviour (13th edition), New York: Prentice Hall.

Salau, O., Adeniji, A., \& Oyewunmi, A. (2014). Relationship between elements of job enrichment and organizational performance among the non-academic staff in Nigeria public universities. Management and Marketing, 3(2), 173-189.

Samwel, J.O. (2018). Human resource planning as an important practice to anticipate future human resource requirements of the organization -Literature review. International Journal of Research in Business Studies and Management, 5(3), 24-30.

Shikha, N.K., \& Karishma, G. (2012). Human resource planning practices. Journal of Business and Management, 3(6), 06-13. 